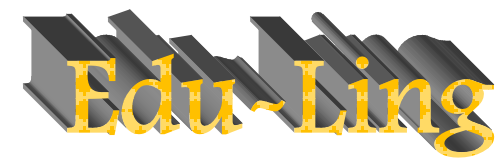

Journal of English Education and Linguistics

\title{
PROBLEMS IN MASTERING ENGLISH: AN ANALYSIS FROM STUDENTS' PERSPECTIVE
}

\author{
Nofrina Eka Putri \\ E-mail: nofrinaekaputri@fbs.unp.ac.id
}

Received on Nov, $19^{\text {nd }}$, Revised on December, $6^{\text {th }}$, Published on December, $30^{\text {st }} 2019$

\begin{abstract}
This research is intended to reveal the problems faced by students in mastering English. This research is categorized into a quantitative study. The sample of this research was 75 students taking MKU Bahasa Inggris (English for General Purposes) class in the second semester of Academic Year 2018/2019. The data were obtained by using the questionnaire, and they then were analyzed quantitatively. The findings showed that to master English, the students get problems related to the limited stock of vocabulary, inability to construct sentences, inability to provide appropriate responses, and lack of opportunities to practice English beyond the class. Based on the findings, it is concluded that the students' less competence in using English has resulted from their basic English capability and environmental supports.
\end{abstract}

Keywords: MKU Bahasa Inggris, Large Class, and Students' Problems

\begin{abstract}
ABSTRAK
Penelitian ini bertujuan untuk mengetahui permasalahan yang dihadapi oleh mahasiswa dalam menguasai bahasa Inggris. Penelitian ini merupakan penelitian kuantitatif. Sampel penelitian adalah 75 orang mahasiswa yang mengambil Mata Kuliah Umum (MKU) Bahasa Inggris pada semester genap 2018/2019. Data dikumpulkan dengan menggunakan angket. Data yang diperoleh diolah secara kuantitatif. Hasil penelitian menunjukkan bahwa selama ini mahasiswa mengalami kesulitan dalam menguasai bahasa Inggris karena keterbatasan kosakata yang mereka miliki, kurangnya kemampuan dalam mengkonstruksi kalimat, kurangnya kemampuan dalam memberi tanggapan yang tepat atas suatu ujaran atau pertanyaan, dan kurangnya kesempatan untuk mempraktekkan bahasa Inggris di luar kelas. Berdasarkan hasil penelitian dapat disimpulkan bahwa rendahnya kompetensi mahasiswa dalam berbahasa Inggris disebabkan oleh faktor-faktor yang berhubungan dengan kemampuan dasar bahasa Inggris, serta dukungan dan kondisi lingkungan.
\end{abstract}

Kata kunci: MKU Bahasa Inggris, Kelas Besar, dan Permasalahan Mahasiswa 


\section{INTRODUCTION}

MKU Bahasa Inggris (similar to English for General Purposes), is one of the required courses that has to be taken by all of students in Padang State University. This class is intended to provide the students with basic knowledge and skills of English that could help them understand numerous texts especially those relevant to their discipline, and enable them to use the language in simple conversations.

As a language class, MKU Bahasa Inggris could be considered as large classes as there are 50 students registered in one class every semester. According to O'Sullivan (2006), a class that consists of 35 students or more is classified as a big class. Those coming to the classes are from different fields of study or departments, and they certainly share different background knowledge and level of competence. Having 50 students in a class with various characteristics surely would raise many obstacles.

Entering one of the classes for the first time gives lecturer an impression that those sitting in the class are very innocent and quiet. They would formally respond the greeting "Good morning, I'm fine, thank you, and you?" smoothly. Having further questions such as "Are you from Padang?, What is your major?, Do you want to be an entrepreneur?, Why don't you want to be a teacher?, What is your father job? or What time is it, now?" make the students dazed and sometimes reticent. They are likely to have problems to grasp the gist of the questions, or seemed to need more time to arrange the words to answers the questions given.

Based on a proficiency test containing basic items of English grammar administered to the students in the first meeting of the semester, it was found that most of the students were unable to provide the best answers. Of 300 students taking the test, around $75 \%$ made score below 50 . In addition, the researchers also held a spoken test requiring students to answer questions related to their everyday activities. The result of the test signified that only few students are able to give appropriate answers or responses. In other words, the students are generally less competent in spoken English. This certainly dissatisfy the finding of research conducted by Putri (2018) arguing that outside, English is highly used in spoken form.

The phenomena above suggest that most of students taking MKU Bahasa Inggris are less competent in English, even for the basic level. This, in fact, is quite surprising because the students taking the class have learned English since they were 
in Elementary School. For such a long time of learning English, those should have been able to perform simple English well.

In the learning process, however, the students seem to be very enthusiastic and show great interest to learn. They notice the lecturer's explanation and satisfactorily complete the tasks assigned at the day. It is clearly seen that the students understand the learning materials and are able to practice what they have already learned. Unfortunately, those students would remain silent when a spoken question is posed. A frown is clearly seen on their forehead showing that they are trying to understand the questions as well as find the appropriate answers for. Additionally, after taking the class for several meetings, the students seemed to forget what they have learned so that they are unable to do the test well in either written or spoken form.

Dealing to the problems faced by students in English classes, there is actually a wide range of research conducted by numerous researchers offering a great number of solutions for various problems, such as those conducted by Argawati (2014), Kazemi (2014), Tahir (2015), and Pourhosein (2016). None of the research, however, sought to figure out the roots of the problems. Many have claimed that the students have lack of competence in English in either written or spoken form, but they did not yet display the reasons for which the students are unable to use English and how they perceive their own English competence. Based on the above phenomena, this research seeks to reveal the problems encountered by students in MKU Bahasa Inggris. The results of the research are expected to provide valuable information for the lecturers in defining the exact problems on teaching and learning MKU Bahasa Inggris as well as to be regarded as inputs in determining the appropriate resolutions.

\section{RESEARCH METHODOLOGY}

This is a quantitative research method. The research was conducted in the second semester of Academic Year 2018/2019. It involved 300 students taking MKU Bahasa Inggris class in that semester. Of the population, 75 students were chosen as the participants. To get the data, a number of statements covered in questionnaire are addressed to the students. The data obtained then were analyzed quantitatively.

\section{RESULT AND DISCUSSION}

The problems of learning MKU Bahasa Inggris in this article are seen from the students' perspective. They are potentially derived from the students' 
attitude and motivation, current English capability, opportunity to practice English, lecturers, and learning materials.

\section{Students' Attitude and Motivation}

Attitude and motivation are two aspects that could promote students' active involvement in the learning process. Having negative attitude and less motivation in learning a subject would make students reluctant and unwilling to participate in classroom activities. Usually, they prefer to sit in the corner of the class or in the back seat. This certainly have an impact on their learning outcomes. Table 1 below shows an overview of students' interest in MKU Bahasa Inggris classes.

Table 1: Students' Attitude and Motivation in Learning English

\begin{tabular}{|c|c|c|c|c|c|c|c|c|}
\hline \multirow[t]{3}{*}{ No. } & \multirow[t]{2}{*}{ Statement } & \multicolumn{4}{|c|}{ Scale } & \multirow[t]{3}{*}{ Total } & \multirow[t]{3}{*}{ Average } & \multirow[t]{2}{*}{ Category } \\
\hline & & Always & Often & Seldom & Never & & & \\
\hline & Interest and Motivation & & & & & & & \\
\hline 1 & I like English & 100 & 102 & 32 & 0 & 234 & 3,12 & OFTEN \\
\hline 2 & $\begin{array}{l}\text { I learn English } \\
\text { persistently }\end{array}$ & 116 & 111 & 18 & 0 & 245 & 3,26 & OFTEN \\
\hline 3 & $\begin{array}{l}\text { I feel motivated to learn } \\
\text { English }\end{array}$ & 120 & 114 & 21 & 0 & 255 & 3,4 & OFTEN \\
\hline
\end{tabular}

The above table displays that the majority of students like English, or in other words, they have positive attitude toward English. Having high score in this aspect is very crucial and may exert influence upon their English achievement (Ditual :2012). Their interest in English helps them to learn English persistently and feel motivated to get engaged in. From the table, it is clearly seen that in general the students do not have problems related to interest and motivation.

\section{Current English Capability}

As the students coming to $\mathrm{MKU}$ Bahasa Inggris have already learned English since primary school, they are certainly expected to have at least basic knowledge in that language. Their previous capability in English are very important to help them in understanding the materials presented. Table 2 below gives a description about the students' English capability. 
Table 2: Current English Capability of the Students

\begin{tabular}{|c|c|c|c|c|c|c|c|c|}
\hline \multirow[t]{3}{*}{ No. } & \multirow[t]{2}{*}{ Statement } & \multicolumn{4}{|c|}{ Scale } & \multirow[t]{2}{*}{ Total } & \multirow[t]{2}{*}{ Average } & \multirow[t]{3}{*}{ Category } \\
\hline & & Always & Often & Seldom & Never & & & \\
\hline & Personal Capabilities & & & & & & & \\
\hline 5 & $\begin{array}{l}\text { I have sufficient } \\
\text { vocabulary }\end{array}$ & 20 & 81 & 84 & 1 & 186 & 2,5 & SELDOM \\
\hline 6 & $\begin{array}{l}\text { I am able to pronounce } \\
\text { words correctly }\end{array}$ & 20 & 99 & 72 & 1 & 192 & 2,6 & OFTEN \\
\hline 7 & $\begin{array}{l}\text { I know the meaning of } \\
\text { the words contained in } \\
\text { my reading }\end{array}$ & 20 & 117 & 62 & 0 & 199 & 2,7 & OFTEN \\
\hline 8 & $\begin{array}{l}\text { I am able to construct } \\
\text { affirmative sentences }\end{array}$ & 24 & 81 & 84 & 0 & 189 & 2,5 & SELDOM \\
\hline 9 & $\begin{array}{l}\text { I am able to construct } \\
\text { interogative sentences }\end{array}$ & 28 & 99 & 70 & 0 & 197 & 2,6 & OFTEN \\
\hline 10 & $\begin{array}{l}\text { I am able to understand } \\
\text { questions addressed to } \\
\text { me }\end{array}$ & 32 & 87 & 72 & 2 & 193 & 2,6 & OFTEN \\
\hline 11 & $\begin{array}{l}\text { I am able to provide } \\
\text { appropriate responses or } \\
\text { answers }\end{array}$ & 32 & 90 & 68 & 3 & 193 & 2,6 & OFTEN \\
\hline 12 & $\begin{array}{l}\text { I remember the material } \\
\text { that I have alreday } \\
\text { learnt }\end{array}$ & 16 & 126 & 58 & 0 & 200 & 2,7 & OFTEN \\
\hline
\end{tabular}

Viewed from their current English capability, Table 2 presents that the students seldom have sufficient vocabulary to facilitate their learning, and are seldom able to construct affirmative sentences. At a glance, it appears that vocabulary and sentence construction are two problems encountered by the students in this aspect. But paying closer attention to the average score of the category ( especially that which is 2,6), it is learnt that students actually also have problems in pronouncing words, constructing interogative sentences, understanding questions, and giving appropriate responses or answers.

\section{Opportunity to Practice English beyond the Class}

In order to check students' understanding on the materials taught and have them practice what have already acquired, lecturers commonly assign students to do certain tasks. These tasks or assignment sometimes must be done in the classroom but not rarely do they need to be completed at home (homework). Doing homework, in fact, cannot be regarded as an opportunity to practice English beyond the classroom as it does not involve active and interactive process. 
Table 3: Students' Opportunity to Practice English beyond the Class

\begin{tabular}{|c|c|c|c|c|c|c|c|c|}
\hline \multirow[t]{2}{*}{ No. } & \multirow[t]{2}{*}{ Statement } & \multicolumn{4}{|c|}{ Scale } & \multirow[t]{3}{*}{ Total } & \multirow[t]{3}{*}{ Average } & \multirow[t]{3}{*}{ Category } \\
\hline & & Always & Often & Seldom & Never & & & \\
\hline & \multicolumn{5}{|c|}{ Opportunity to Practice English beyond the Class } & & & \\
\hline 13 & $\begin{array}{l}\text { I have friends to } \\
\text { practive English out of } \\
\text { the class }\end{array}$ & 48 & 54 & 72 & 9 & 183 & 2,4 & SELDOM \\
\hline 14 & $\begin{array}{l}\text { There are certain } \\
\text { conditions that require } \\
\text { me to use English out of } \\
\text { the class }\end{array}$ & 20 & 66 & 80 & 8 & 174 & 2,3 & SELDOM \\
\hline
\end{tabular}

The above table clearly signifies that students seldom have chances to practice English out of the classroom and they rarely found certain condition that require them to use that language in everyday life. In other words, students are only exposed to and use English in MKU Bahasa Inggris class. Soon the class period ends, they no longer needs to think and act in that language. Whereas, in order to be able to perform in a certain language, a continuous practice is really needed. It could activate the vocabulary acquired, help students memorize the words and improve their fluency. From Table 3, it is identified that students have problems related to practicing English out of the class.

\section{Lecturer}

The following table presents the students' perception toward the lecturers teaching in MKU Bahasa Inggris classes.

Table 4: Problems Related to Lecturers

\begin{tabular}{|c|c|c|c|c|c|c|c|c|}
\hline \multirow[t]{3}{*}{ No. } & \multirow[t]{2}{*}{ Statement } & \multicolumn{4}{|c|}{ Scale } & \multirow[t]{3}{*}{ Total } & \multirow[t]{3}{*}{ Average } & \multirow[t]{3}{*}{ Category } \\
\hline & & Always & Often & Seldom & Never & & & \\
\hline & Lecturer & & & & & & & \\
\hline 15 & $\begin{array}{l}\text { The lecturer explains } \\
\text { the materials clearly }\end{array}$ & 196 & 66 & 8 & 0 & 270 & 3,6 & ALWAYS \\
\hline 16 & $\begin{array}{l}\text { Te lecturer provides } \\
\text { sufficient exercises }\end{array}$ & 176 & 75 & 12 & 0 & 263 & 3,5 & OFTEN \\
\hline 17 & $\begin{array}{l}\text { I already mastered the } \\
\text { materials when the } \\
\text { lecturer came to the } \\
\text { new topic }\end{array}$ & 36 & 135 & 38 & 2 & 211 & 2,8 & OFTEN \\
\hline 18 & The lecturer is pleasant & 208 & 66 & 2 & 0 & 276 & 3,7 & ALWAYS \\
\hline
\end{tabular}

Based on the data presented in Table 4, it does not seem that students have problems related to the lecturers. They view that the lecturers always explain the 
materials clearly, and often provide sufficient exercises to the students. Before cming to the new topic, the students have already mastered the previous lessons. In addition, the lecturers are always pleasant.

\section{Teaching Materials}

Teaching materials play an important role in facilitating students to gain success in their English learning. The following is the students' perception toward the materials presented in MKU Bahasa Inggris class.

Table 5: Problems related to Teaching Materials

\begin{tabular}{|ccccccccc}
\hline No. & \multicolumn{1}{c}{ Statement } & \multicolumn{4}{c}{ Scale } & Total & Average & Category \\
\cline { 3 - 6 } & Always & Often & Seldom & Never & & & \\
\hline 19 & $\begin{array}{l}\text { Teaching Materials } \\
\text { The materials presented } \\
\text { are interesting }\end{array}$ & 88 & 135 & 16 & 0 & 239 & 3,2 & OFTEN \\
\hline
\end{tabular}

The above table shows that the students do not have problems related to the teaching materials. They think that the materials presented are interesting. In other words, their lacks in English are unlikely resulted from materials aspect.

\section{CONCLUSIONS}

Based on the results of data analysis, it is figured out that the students' less competence in English is resulted from several problems, including, The students have limited vocabulary The students are less capable in constructing sentences (either affirmative or interrogative ones). The students rarely get friends to practice English beyond the classroom. There are no any situation or conditions that require students to use English out of the classroom
Although not identified as problems, the students' capability in understanding questions and provide responses toward statements or questions addressed to them need serious attention.

\section{REFERENCE}

Argawati, N. O. (2014). Improving Students' Speaking Skill Using Group Discussion (Experimental study on the First Grade Students of Senior High School). ELTIN JOURNAL, Journal of English Language Teaching in Indonesia, 2(2).

Ditual, R. C. (2012). The motivation for and attitude towards learning English. Asian EFL Journal, 63, 4-21.

Kazemi, M., Katiraei, S., \& Rasekh, A. E. (2014). The impact of teaching lexical 
bundles on improving Iranian EFL students' writing skill. Procedia-Social and Behavioral Sciences, 98, 864-869.

Putri, N. E., Kher, D. F., Rani, Y. A., \& Ramli, A. J. (2018). English For Specific Purposes: English Language Needs in Hospitality and Travel Industry. IJMURHICA: International Journal of Multidisciplinary Research of Higher Education, 1(1), 1-17.

O’Sullivan, M.C. (2006) Teaching large classes: The international evidence and a discussion of some good practices in Ugandan primary schools. International Journal of Educational Development, 26, 24-37

Pourhosein Gilakjani, A., \& Sabouri, N. B. (2016). How can students improve their reading comprehension skill. Journal of Studies in Education, 6(2), $229-240$.

Tahir, S. Z. A. B. (2015). Improving Students' Speaking Skill through Yahoo Messenger at University of Iqra Buru. International Journal of Language and Linguistics, 3(3), 174181. 